\title{
Effect of the Project-Work Learning Model to Improve the Quality of Vocational Education in Indonesia
}

\author{
Dwi Rahdiyanta, Asnawi \\ Universitas Negeri Yogyakarta \\ Yogyakarta, Indonesia \\ dwi_rahdiyanta@uny.ac.id
}

\begin{abstract}
This study aims to find: (1) the project-work learning model based a characters to improve the quality of vocational education; (2) the effect of the implementation of project-work learning model based a character of the attitudes and achievement of students. This study is a research development continued with the experiment. This research was conducted in the machining industry in the region of Yogyakarta and Central Java and in the Study Program of Mechanical Engineering, Faculty of Engineering, Yogyakarta State University, Indonesia. The population of this study were all students who are taking courses complex machining processes, totaling 85 students. These samples included 33 students is determined by purposive sampling technique. Experimental design used is the posttest-only control design. The instrument validation is done by expert judgment. The data were analyzed with descriptive analysis and t-test, with significance level of 0.05 . The results showed that: (1) The learning model of projectwork based a character suited to improve the quality of learning outcomes in the machining process on vocational higher education; (2) Attitude and achievement of students in the class model is better than the class conventional. (Abstract)
\end{abstract}

Keywords -- learning model; project-work; character.

\section{INTRODUCTION}

Vocational higher education as part of the national education system in Indonesia, played a very strategic role for the realization of a highly skilled workforce and ready to work. To form graduates who are skilled and ready for the work, the students must have competency in the academic field (hard skills), and have a noble character or character values (soft-skills). In vocational education, the course of practice, is a subject which has a very important and strategic position to form graduates who are ready to work. Therefore, the course of practice, is a characteristic on vocational education. Thus, for vocational education can actually produce graduates who are ready to work, required to always improve the quality of practice learning process, either in the workshop or in the laboratory. In order to practice learning to be effective, both in providing academic competence and in instilling the values of character, it is necessary to the development and implementation of practice learning model to integrate aspects of hard-skills and soft-skills in the learning process

Basically, any goods produced by a manufacturing industry, especially in the fields of machining, composed of several parts or components are assembled into a particular product. To produce high-quality products that are certainly needed competencies both academic competencies (hard skills), and competencies associated with the character values (soft-skills). Character values that need to be imparted to the students is the attitude of meticulous, painstaking, disciplined, caring, independent, confident, cooperation skills, and honest. In the process of making a product that is composed of many components certainly needed a good working processes and systematic. The working system is often referred to as projectwork. Therefore, in order that the students are familiar with the work system in the manufacturing industry, the learning model of project-work based on the character needs to be applied in practice learning in vocational education.

The notion of vocational education was developed from the translation of the concept of vocational education and occupational education, which means an educational program that is directly connected with the preparation of a person to enter the world of work, or for additional preparation needed in a career [1]. Vocational education is defined as education that provides supplies to students in order to work to sustain its life [2]. Based on these opinions mean that vocational education is needed to prepare students to be ready for work in the neighborhood and outside communities, the primary mission of educators and policy-makers is to set up a strong foundation in the learning process for the student to mastery and application academic skills and concepts necessary to get into the real working world. So that vocational education can produce graduates who are ready to work, need to pay attention to the principles which include: 1) vocational education is effective only be given if the task of the exercise is done in a way, tools, and machinery the same as those applied in the workplace; 2) vocational education will be effective if people are trained directly and specifically to familiarize work and thinking on a regular basis; and 3) develop the habit of effective work to the student would occur 
only if the training and learning will involve real work and not just exercise [3]. Based on the various opinions on the above, it is clear that the focus of vocational education is to equip students with a set of skills and abilities that can be used for work or develop itself in accordance expertise. Thus, preparation of standards of competence in accordance with the demands of work or industry is needed in order to improve the quality of higher vocational education.

Project-work learning is a learning process that gives a strong emphasis on problem solving as a collaborative [4]. In addition to increasingly collaborative, project-work also must be innovative, unique, and focus on solving real problems related to societal needs [5]. Project-based learning is an innovative approach to learning, which emphasizes contextual learning, through the complex activities [6]. The focus of learning lies in the cultivation of the core concepts and principles of a discipline of study, involving learners in the investigation of problem solving and allow learners to work autonomously construct their own knowledge, to produce tangible products [7. Thus this project-based learning has tremendous potential to make the learning experience more interesting and meaningful.

Character education holds a very important role to solve national problems that developed at this time, such as the shifting of ethical values in the life of the nation, waning awareness of the cultural values of the nation, the threat of national disintegration and weakening of the independence of the nation. Character education contains three main elements, namely know the good, loving the good, and doing the good [8]. There are four approaches that need to be done in the field of character education, namely the realization of the values, character education, civic education, and moral education [9]. Realization of values that are important to be imparted to students is: know yourself, awareness of self-esteem, ability to set goals, thinking skills, decision making skills, communication skills, social skills, academic knowledge, and transcendental knowledge. Character education that needs to be imparted to the students include: respect, responsibility, compassion, discipline, loyalty, courage, tolerance, openness, work ethic, and the belief and devotion to God. The major aspects of civic education that needs to be invested include: the knowledge to be a good citizen, an appreciation of the democratic system and the values of citizenship, critical thinking skills, communication skills, collaboration skills, and skills to resolve conflicts. While the moral education includes knowledge, attitudes, beliefs, skills, behaviors are good, honest, and compassionate. The main goal of moral education is to produce autonomous individuals, who understand the moral values and a commitment to act consistently with those values [10].

Character education is not just to teach what is right and wrong to the students, but more than that, the character education instill good habits so that learners understand, able to feel, and want to do good. Education characters carry the same mission with moral education. If it is associated with the characteristics of the machining practice learning the aspects of character that needs to be imparted to students is an honest, disciplined, diligent, thorough, independent, hard-working and caring. Based on the above mentioned fact, be the responsibility of vocational education to produce graduates who besides having academic competence also of noble character. Therefore it is considered very important to improve the quality of practice learning by integrating aspects of hard skills and soft-skills. One of the efforts to integrate the values of characters in a practical lesson is to develop a project-work learning model based on the character in higher vocational education. The issues that will be discussed in this study are: (1) whether the application of project-work learning model based on the character of the course practice civilizing influence on the character of the students ?, and (2) whether the application of project-work learning model based on the character of the course practices affect the increase in student achievement in the subject of machining processes?

\section{RESEARCH METHODS}

This study uses the approach of Research and Development [11], and continued with the experiment. The development of the model in this study through the stages of conceptual models, theoretical models, hypothetical model, and the final model. The development of the model in this study through FGD (Focus Group Discussion), the Delphi technique, and experiments. The stages of development model can be seen in Figure 1 below.

Implementation activities on the learning model of project-work based on characters in the course of machining process is performed using experimental design that posttestonly control design. Determination of the experimental design is based on that in practice learning, assessment of student achievement determined by the product of practice, so it is not necessary pretest.

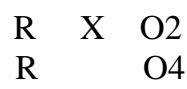

Figure 1. Posttest-Only Control Design

Information :

$\mathrm{R}=$ the control class and experimental class, taken randomly $\mathrm{O} 2=$ posttest experimental class

$\mathrm{O} 4=$ posttest control class

The population is all students of the Diploma in Mechanical Engineering Study Program, Faculty of Engineering, Yogyakarta State University, which is taking courses in Complex Machining Processes. The population number is 85 students. Samples are 33 students consisting of two groups of practical classes, each with 16 and 17 students. The research sample is determined by purposive sampling. The location of this research is in the Mechanical Engineering Study Program, Faculty of Engineering, Yogyakarta State University, and in the machining industry in Yogyakarta Special Region. 
The techniques of collection data in this research are: (1) the observation sheet, (2) documentation, (3) interviews to explore the responses of both students and lecturers, and (4) the assessment sheet. The data were analyzed by means of qualitative and quantitative. To test the effect of the model developed in comparison with the old model, were analyzed using t-test. Before analyzing the t-test, first tested the normality and homogeneity of research data.

\section{RESULTS AND DISCUSSION}

\section{The resulting model}

The development of practice learning model in this study through four stages: conceptual models, theoretical models, hypothetical model, and the final model. In detail the stages of the development of project-work learning model based on a character can be seen in Figure 1 below.

\section{Stages Research R \& D}

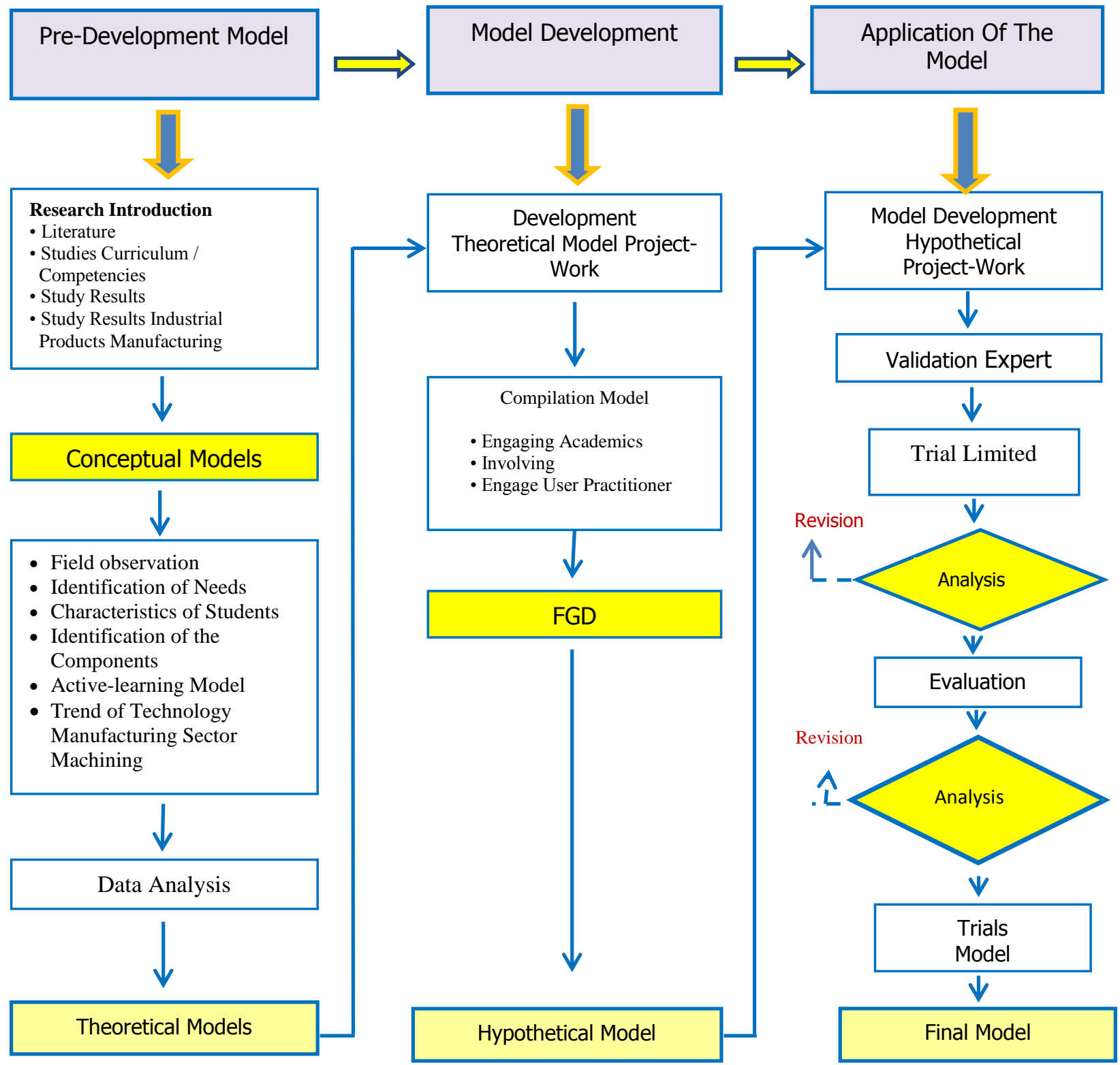

Fig. 2. Model development

From the final stages of the development of the model, it was determined the formulation of the final model of the learning model of project-work based on character for the courses practice in vocational colleges. The formulation of the final model that was implemented in this study can be seen in Figure 3 below. 


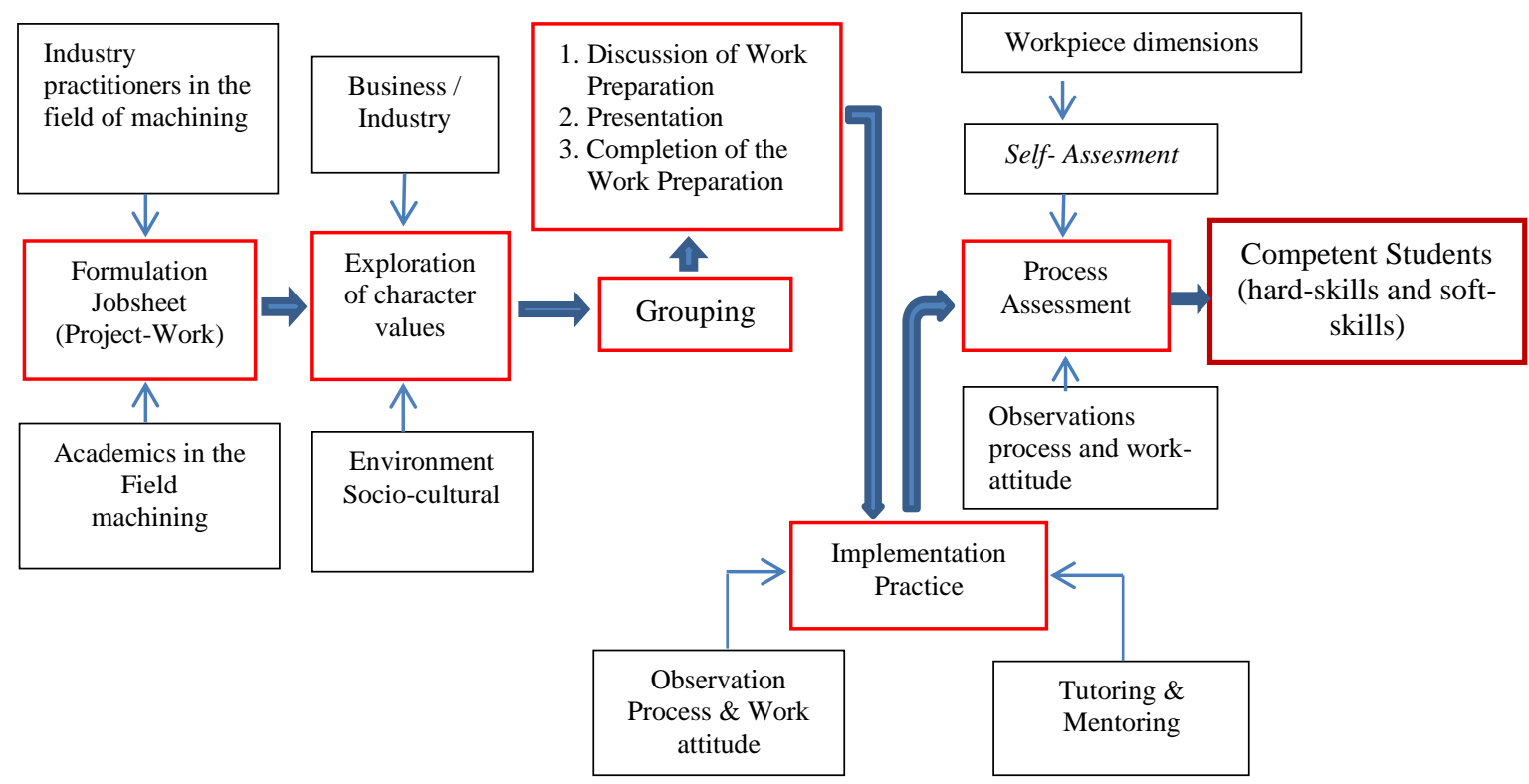

Fig.3. The final models

\section{Implementation of the model}

Implementation of the learning model of project-work based on the character, performed in the course Complex Machining Process. The research process was conducted over eight meetings. First and second meeting was used for description and preparation of learning activities, while the third to the eighth meeting of the core of the research activities. In accordance with the characteristics of the course of practice, the applied aspects of attitude is: honest, disciplined, diligent, thorough, independent, hard-working and caring. Aspects of student achievement is reflected in the work processes and products based on job-sheet in the form of project-work. The project-work in this research is the manufacture of speed-reducer which consists of three main components: 1) the worm gear, 2) shaft worm gear, and 3) shaft worm screw.

Data on the observation of the attitudes of students in the experimental class can be seen in Table 1 below.

TABLE 1. THE ATTITUDE OF THE STUDENTS IN THE EXPERIMENTAL CLASS

\begin{tabular}{|l|c|c|c|c|c|c|}
\hline \multirow{2}{*}{$\begin{array}{c}\text { Aspects of } \\
\text { Character }\end{array}$} & \multicolumn{6}{|c|}{ Number of Students at the meeting } \\
\cline { 2 - 7 } & $\mathbf{3}$ & $\mathbf{4}$ & $\mathbf{5}$ & $\mathbf{6}$ & $\mathbf{7}$ & $\mathbf{8}$ \\
\hline Honest & 8 & 12 & 12 & 14 & 16 & 16 \\
\hline Discipline & 9 & 13 & 15 & 15 & 16 & 16 \\
\hline persevering & 7 & 11 & 12 & 12 & 14 & 16 \\
\hline conscientious & 7 & 11 & 12 & 13 & 14 & 15 \\
\hline Independently & 6 & 12 & 13 & 13 & 14 & 15 \\
\hline Hard work & 5 & 10 & 12 & 14 & 14 & 15 \\
\hline Care & 10 & 12 & 13 & 13 & 14 & 16 \\
\hline Percentage (\%) & $43 \%$ & $66 \%$ & $73 \%$ & $78 \%$ & $85 \%$ & $91 \%$ \\
\hline
\end{tabular}

To give a better picture of the attitudes or activities of students in the experimental class, can be presented with a histogram in Figure 4 below.

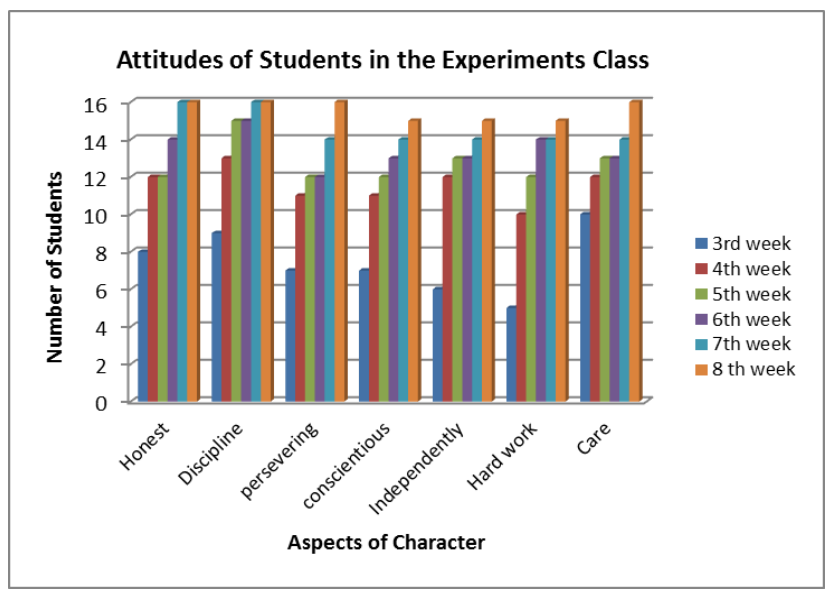

Fig. 4. Histogram attitude of students in the experiment class

From the above data it can be seen that from the meeting on the 3rd week until the 8th week, for all aspects of the character of students experienced a consistent increase. For the aspects of character: honest, disciplined, diligent and concerned at the 8th week or at the end of practice learning, all students of 16 people has been implementing aspects of the well (100\% success). As for the aspects of the character: rigorous, independent and hard work, despite experiencing excellent improvement on the 8th week, but has not fully implement these aspects. In this case there one student who has not been able to implement this aspect. While data on the observation of the attitudes or activity of students in the control class, can be seen in Table 2 below. 
TABLE 2. THE ATTITUDE OF THE STUDENTS IN THE CONTROL CLASS

\begin{tabular}{|l|c|c|c|c|c|c|}
\hline \multirow{2}{*}{$\begin{array}{c}\text { Aspects of } \\
\text { Character }\end{array}$} & \multicolumn{7}{|c|}{ Number of Students at the meeting } \\
\cline { 2 - 7 } & $\mathbf{3}$ & $\mathbf{4}$ & $\mathbf{5}$ & $\mathbf{6}$ & $\mathbf{7}$ & $\mathbf{8}$ \\
\hline Honest & 5 & 6 & 9 & 9 & 12 & 12 \\
\hline Discipline & 7 & 7 & 8 & 10 & 10 & 12 \\
\hline persevering & 4 & 5 & 6 & 6 & 8 & 10 \\
\hline conscientious & 5 & 6 & 6 & 4 & 7 & 8 \\
\hline Independently & 5 & 6 & 5 & 7 & 6 & 9 \\
\hline Hard work & 6 & 5 & 7 & 5 & 5 & 7 \\
\hline Care & 4 & 6 & 6 & 8 & 11 & 9 \\
\hline Percentage & $\mathbf{2 9 \%}$ & $\mathbf{3 3 \%}$ & $\mathbf{3 8 \%}$ & $\mathbf{4 0} \%$ & $\mathbf{4 9 \%}$ & $\mathbf{5 5 \%}$ \\
\hline
\end{tabular}

TABLE 3. LEARNING ACHIEVEMENT OF STUDENTS IN THE EXPERIMENT CLASS AND CONTROL CLASS

\begin{tabular}{|c|c|c|c|c|c|c|c|c|}
\hline \multirow{2}{*}{ Student } & \multicolumn{4}{|c|}{ Experiment Class } & \multicolumn{4}{c|}{ Control Class } \\
\cline { 2 - 9 } & Job I & Job II & Job III & Mean & Job I & Job II & Job III & Mean \\
\hline 1 & 82 & 78 & 81 & 80.33 & 65 & 66 & 70 & 67.00 \\
\hline 2 & 80 & 80 & 80 & 80.00 & 60 & 65 & 65 & 63.33 \\
\hline 3 & 81 & 85 & 85 & 83.67 & 70 & 68 & 68 & 68.67 \\
\hline 4 & 79 & 80 & 82 & 80.33 & 72 & 70 & 70 & 70.67 \\
\hline 5 & 79 & 83 & 79 & 80.33 & 68 & 70 & 66 & 68.00 \\
\hline 6 & 80 & 82 & 82 & 81.33 & 72 & 60 & 60 & 64.00 \\
\hline 7 & 82 & 85 & 80 & 79.00 & 68 & 62 & 65 & 65.00 \\
\hline 8 & 77 & 80 & 80 & 79.00 & 70 & 65 & 62 & 65.33 \\
\hline 9 & 78 & 80 & 79 & 79.00 & 70 & 60 & 66 & 67.33 \\
\hline 10 & 80 & 79 & 82 & 80.33 & 65 & 65 & 72 & 67.33 \\
\hline 11 & 80 & 85 & 80 & 81.67 & 60 & 72 & 68 & 66.67 \\
\hline 12 & 82 & 85 & 80 & 82.33 & 70 & 66 & 60 & 65.33 \\
\hline 13 & 85 & 85 & 85 & 85.00 & 65 & 70 & 65 & 66.67 \\
\hline 14 & 80 & 82 & 82 & 81.33 & 60 & 65 & 65 & 63.33 \\
\hline 15 & 82 & 80 & 81 & 81.00 & 70 & 66 & 60 & 65.33 \\
\hline 16 & 80 & 79 & 82 & 80.00 & 72 & 60 & 60 & 64.00 \\
\hline 17 & - & - & - & - & 72 & 70 & 70 & 70.67 \\
\hline \multicolumn{7}{|c|}{ The average value of } \\
the class experiment & 81.15 & $\begin{array}{l}\text { The average value of the } \\
\text { class control }\end{array}$ & 66.33 \\
\hline
\end{tabular}

A description of the learning achievement of machining practices in the experimental class students can also be seen in Figure 6 below.

\section{Achievement Of Students In The Experiment Class}

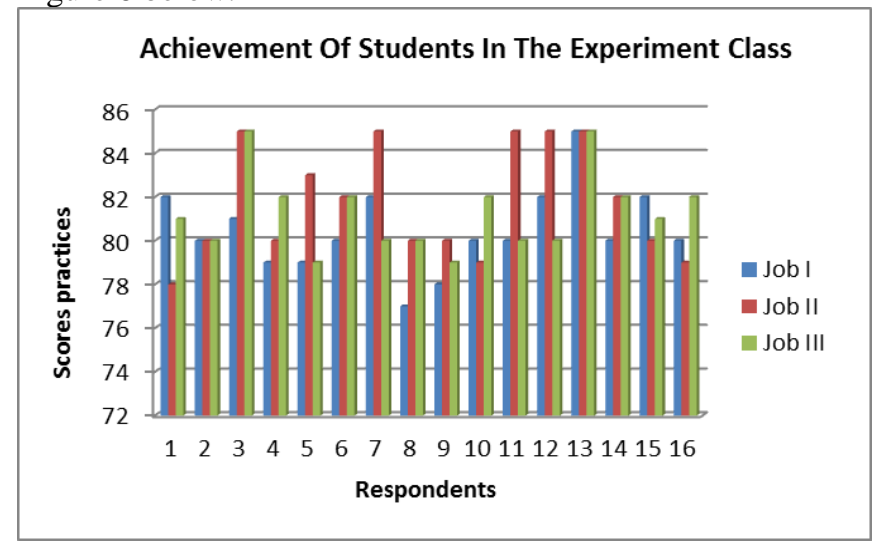

Fig. 5. Histogram achievements of students in the experiments class
Based on the above data it can be seen that from the meeting on the 3rd week until the 8th week, only $55 \%$ of students who have been implementing aspects of the character. From the research data can also be seen that the increase in the implementation of aspects of characters thorough, independent, hard-working, caring inconsistent. The student achievement data is obtained from the assessment of the work process and product workpieces results of student practice based on job-sheet manufacture of speed-reducer, which consists of three components, that is: 1) the worm gear, 2) shaft worm gear, and 3) worm screw shaft. The complete data is the achievement of students in the experimental class and the control class can be seen in Table 3 below.
A description of the achievement of students in the control class can also be seen in Figure 6 below.

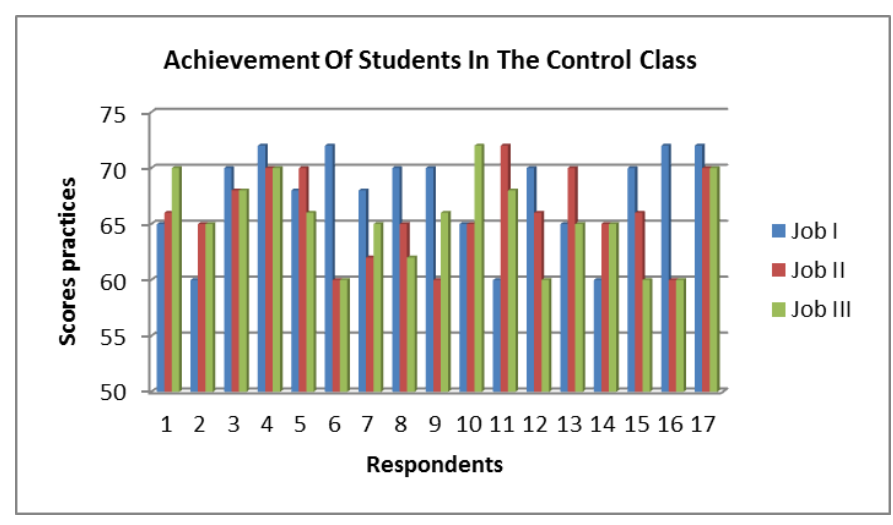

Fig.6 Histogram Achievement of Student in the Control Class 
The next stage of test requirements analysis is done according to the type of analysis that will be used to determine differences in attitudes and student achievement between the experimental class and control class. Test requirements analysis covering the normality and homogeneity test.

\section{Normality Test.}

To test the research data were normally distributed or not, is done by looking at the ratio of the value of the ratio of skewness and kurtosis. Data can be said to be normally distributed if the value of the ratio of skewness and kurtosis are in the range of -2 to +2 . Data normality test results of research conducted using SPSS (Statistics Program for Social Science) version 16.0 for Window.

From the data normality test for the achievement of students in the experimental class, based on the ratio of skewness and kurtosis techniques, showed that the ratio of the value of skewness $(-1.748)$ and the ratio of kurtosis $(\neg 0,288)$ is in the range of -2 to +2 . Based on these results we can conclude that the achievement data of students in the experimental class are normally distributed.

Data normality test results of students attitude in the class control, based on the technique of skewness and kurtosis ratio shows that the value of skewness variable ratio $(0.821)$ and the ratio of kurtosis $(-0.370)$ is in the range of -2 to +2 . Therefore means that research data regarding the attitude of the students is a normal distribution.

\section{Homogeneity test}

Summary results of the data homogeneity test of student achievement can be seen in Table 5 below.

TABLE 5. SUMMARY OF TEST HOMOGENEITY OF ACHIEVEMENT

\begin{tabular}{|l|r|r|r|r|}
\hline & \multicolumn{1}{|c|}{$\begin{array}{l}\text { Levene } \\
\text { Statistic }\end{array}$} & df1 & \multicolumn{1}{c|}{ df2 } & \multicolumn{1}{c|}{ Sig. } \\
\hline $\begin{array}{l}\text { Value_Achievement } \\
\text { Based on Mean } \\
\text { Based on Median }\end{array}$ & 1.802 & 1 & 31 & .189 \\
\hline
\end{tabular}

\begin{tabular}{|l|r|r|r|r|}
\hline $\begin{array}{l}\text { Based on Median } \\
\text { and with adjusted df }\end{array}$ & .546 & 1 & 24.483 & .467 \\
$\begin{array}{l}\text { Based on trimmed } \\
\text { mean }\end{array}$ & 1.578 & 1 & 31 & .218 \\
\hline
\end{tabular}

The results of testing the homogeneity of the research data obtained by Levene statistical significance of 0.189 , on Based on Mean larger 0.05. Thus, the data research achievement of students is homogeneous.

Results of testing the homogeneity of the data students' attitude can be seen in Table 6 below.

TABLE 6. THE SUMMARY OF RESULTS OF TESTING THE HOMOGENEITY OF DATA ON ATTITUDES LEARNING

\begin{tabular}{|l|c|c|c|c|}
\hline & $\begin{array}{c}\text { Levene } \\
\text { Statistic }\end{array}$ & df1 & df2 & Sig. \\
\hline \multicolumn{1}{|c|}{ Value_Attitude } & .776 & 1 & 12 & .394 \\
Based on Mean & .166 & 1 & 12 & .690 \\
Based on Median & .166 & 1 & 9.902 & .690 \\
Based on Median and & .734 & 1 & 12 & .407 \\
with adjusted df & Based on trimmed mean & .7 &
\end{tabular}

Based on test results obtained with Levene statistical significance at 0.394 Based on Mean greater than 0.05. Thus the research data regarding the attitude of students is homogeneous. Based on the test results of the analysis requirements, the different test can be done with parametric tests, so that the data analysis technique used is the t-test. The results of the analysis of data has been carried out are as follows:

\section{The result of t-test}

The results of the t-test on the achievement of students between the experimental class and control class can be seen in the following table 6 .

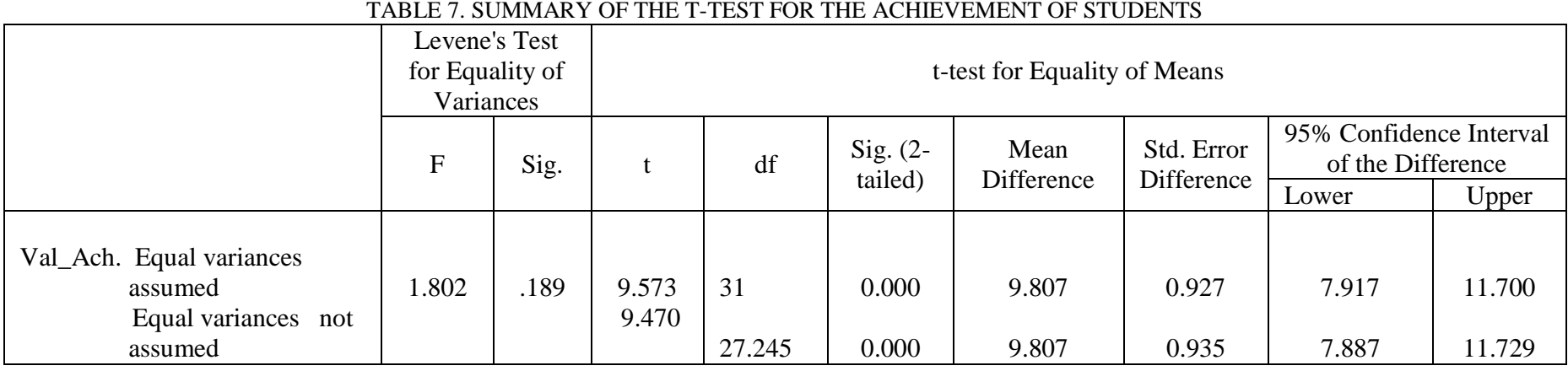

Based on the results of $\mathrm{t}$-test, known that the value $\mathrm{t}=$ 9.573 with 0.000 significance. Thus, it means there is a significant difference between the achievement of students in the experimental class and control class. The average value of the achievement of students in the experimental class is bigger than the control class $(\mathrm{X}$ experiments $=81.15>\mathrm{X}$ control $=$ 66.33).
Based on t-test, we can conclude that the project-work learning model based on the character can improve the achievement of students. Thus, this model is suitable for use in the course of machining process in higher vocational education. 


\section{The Attitudes Of Students}

Based on the results of the t-test, known that the value $t$ $=7.211$ with 0.000 significance. Thus, it means there is a significant difference between the attitudes of students in the experimental class and control class. The average amount of the percentage of students who have to implement aspects of the character of the experimental class is bigger than the control class $(X$ experiments $=91 \%>X$ control $=55 \%$ ).

Based on t-test, we can conclude that the learning model of project-work based on the character can improve the attitudes of students. Thus, this model is suitable for use in the course of machining process in higher vocational education.

TABLE 8. SUMMARY OF THE T-TEST FOR THE ATTITUDES OF STUDENTS

\begin{tabular}{|c|c|c|c|c|c|c|c|c|c|}
\hline & \multicolumn{2}{|c|}{$\begin{array}{c}\text { Levene's Test } \\
\text { for Equality of } \\
\text { Variances } \\
\end{array}$} & \multicolumn{7}{|c|}{ t-test for Equality of Means } \\
\hline & \multirow[t]{2}{*}{$\mathrm{F}$} & \multirow[t]{2}{*}{ Sig. } & \multirow[t]{2}{*}{$\mathrm{t}$} & \multirow[t]{2}{*}{ df } & \multirow{2}{*}{$\begin{array}{l}\text { Sig. } \\
(2- \\
\text { tailed })\end{array}$} & \multirow[t]{2}{*}{$\begin{array}{c}\text { Mean } \\
\text { Difference }\end{array}$} & \multirow{2}{*}{$\begin{array}{l}\text { Std. Error } \\
\text { Differenc } \\
\text { e }\end{array}$} & \multicolumn{2}{|c|}{$\begin{array}{l}\text { 95\% Confidence } \\
\text { Interval of the } \\
\text { Difference }\end{array}$} \\
\hline & & & & & & & & Lower & Upper \\
\hline $\begin{array}{ll}\text { Obs_Att. } & \text { Equal variances } \\
& \text { assumed } \\
& \text { Equal variances } \\
& \text { not assumed }\end{array}$ & 0.776 & 0.394 & $\begin{array}{l}7.211 \\
7.211\end{array}$ & $\begin{array}{c}12 \\
11.420\end{array}$ & $\begin{array}{l}0.000 \\
0.000\end{array}$ & $\begin{array}{l}5.429 \\
5.429\end{array}$ & $\begin{array}{l}0.753 \\
0.753\end{array}$ & $\begin{array}{l}3.789 \\
3.780\end{array}$ & $\begin{array}{l}7.070 \\
7.079\end{array}$ \\
\hline
\end{tabular}

Based on the results of the implementation of the model, it is evident that the learning model of project-work based on the character, able to integrate aspects of attitudes or behaviors (soft-skills) with aspects of academic competence (hard-skill) in the learning of the machining process. The integration of aspects of soft-skill and hard-skills can be seen from the activity or behavior of students during the learning process. Based on observations during the implementation process, particularly in the exploration stage on the aspects of the work attitude, it appears that learning practices using the learning model of project-work based on character is very effective to engage learners in exploring and cultivating an attitude of working in the machining process. At the stage of exploration aspects of the work attitude, learners are required to express their opinions regarding the aspects of the work attitude that should be owned by a person, especially in carrying out work related to the machining process. The purpose of the implementation of this phase is when someone has had a consciousness theoretically related to aspects of the character (as seen from the discussion process of delivering the opinion by learners related to aspects of the character), then logically a person will certainly carry out wholeheartedly against various aspects of the character associated with machining practices are held on campus. Thus the character of the work that has been believed, understood and practiced in the learning process in the end of course also be implemented in the real working world.

From the observation of the activity of students during the learning process takes place, it is evident that learners are actively express their opinions during the process of exploration in the aspect of attitude, it turns out during the learning process, they have a good working attitude. So that the exploration stage on the aspects of the work attitude is indeed effective in integrating aspects of the characters in the learning process.

Another important stages to be considered in the implementation the learning model of project-work based on the character, is a discussion in the preparation of work plans (Preparation Work Sheet). At this stage, learners are required to work together to resolve the issue and respect the opinion of other people, both friends in the group and other groups. So that by passing this stage, they are able to familiarize learners to dare to argue, respect the opinions of others, and cooperation. By getting a discussion to solve a problem, the students also have embedded critical thinking skills, and troubleshooting skills. Critical thinking can lead to the formation of discreet nature. Critical thinking allows one to analyze the information carefully and make the right decisions in the face of controversial issues. Here fore, it is expected the role of educators to familiarize students to think critically, to provide activities that contain characteristics which includes: (1) sought to clarify the statement or question, (2) finding the reasons, ( 3 ) trying to get the right information, (4) using reliable sources, (5) consider the overall situation, (6) search for alternatives, (7) being open, (8) to change the view if there is credible evidence, (9) look for the accuracy of a problem, and (10) sensitive to the feelings, knowledge, and level of sophistication of others [9].

Based on the results of the implementation of learning model that has been implemented, proved to be an integration between hard skills and soft-skills in the learning process of machining practices. It is shown from the difference in the activity of students during the learning process takes place. In the class that implements the projectwork learning model based on the character, proved to be much more active or better when compared with classes that do not use the learning model. Based on the results of this research can also be seen that the level of activity of learners is directly proportional to the achievement of learners. This means that the higher the level of activity of learners, the higher the academic achievement.

Some of the facts above, according to research shows the increase of student motivation in schools that implementing character education [12]. The classes are comprehensively engaged in character education, showed a drastic reduction in negative student behaviors that can hinder learning success. It is also in line with the opinion which states that the risk factors that lead to the failure of the students was not solely lie in intelligence, but also on the character, which 
include: self-confidence, ability to work together, social skills, ability to concentrate, empathy, and communication skills. Similarly, if it is associated with the opinion that the learning model of project-work based on the character, is a comprehensive learning approach, because it contains aspects: inculcation, modeling, and skills development [9].

Aspects of value investment can be characterized as follows: (1) communicate confidence with right reason, (2) respect the views of others, (3) create a social experience and emotional about the values that you want, and (4) make the rules, rewards, and consequences with the right reasons. Aspects of the exemplary values can cultivate assertive skills and listening skills in learners. These skills are required to build relationships between individuals and between groups. Assertive skills are the skills to express opinions openly, in ways that do not hurt the other person. Listening skill is the skill of listening with understanding and critically. Both of these listening skills, described as "yin and yang", both of which should be developed in a balanced manner as a vital component of communication. The aspects of facilitation value, is a help or guidance from educators for learners to cope with her problems. The activities of facilitation values, a proven positive impact on personality development of students, which include: (1) improve the relationship of teachers and students, (2) help students clarify understanding, (3) encourage students to think more about values learn, find the insights themselves, and ultimately realize the goodness of things that are delivered by educators, (4) educators better understand the thoughts and feelings of learners, and (5) to motivate learners to connect the issue of the value of life, beliefs, and feelings of their own [10].

\section{CONCLUSION}

1. The learning model of project-work based on the character is very well used to improve the quality of the learning process of machining practices at vocational higher education.

2. There are differences in student attitudes are very significant between students taught using the learning model of projectwork based on a characters, compared with students who are not taught by the learning model of project-work based on the character in the course of machining practices $(t=7.21$; $p=0.000)$. The percentage of implementation of the values of character by students who were taught by applying the learning model of project-work based on the character, better than the students who were taught not using the learning model of project-work based on the character (X experiments $=91 \%>\mathrm{X}$ control $=55 \%$ ).

3. There are differences in student achievement is very significant between students taught with the learning model of project-work based on a character, compared with students who are not taught with the learning model of project-work based on the character $(t=9.57 ; \mathrm{p}=0.000)$. The average achievement of students taught by applying the learning model of project-work based on the character higher than the achievement of students who were taught not using the learning model of project-work based on the character in the course of machining practices (X experiments $=81.15>\mathrm{X}$ control $=66.33$ )

\section{SUGGESTIONS}

Based on the conclusions that have been formulated, there are some things that can be used as a suggestion, namely:

1. Learning model that has been developed has proved effective in instilling character of work in learning the machining process. Therefore, this model needs to be tested on subjects other practices.

2. Implementation of the learning model of project-work based on the character, needed portion of the lot to observe the activities of students during the learning process. Therefore, the role of the lecturer should be more focused on the process of coaching and mentoring to students.

\section{REFERENCES}

[1] Calhoun, C.C. and Finch,C.R., Vocational Educational: Concepts And Operation, Belmont: Wadsworth Publishing Company, 1976.

[2] Finch, C.R. and Crunkilton, J.R., Curriculum Development In Vocational Education, Boston: Allyn and Bacon Inc, 1979.

[3] Prosser, C.A., \& Allen, C.R., Vocational Education in a Democracy. New York: Century, 1952.

[4] Fortus, D., et al., Incorporating modeling practices into middle school project-based science. Research report: Weizmann Institute of Science, 2005.

[5] Alamaki, A. (2004). Current trends in technology education in Findland. The Journal of Technology Studies. Taken on March 3, 2016, from http://cholar.lib.vt.edu/ejournals 000/alamaki.html.

[6] Bern, R.G., \& Erikson, P.M., Contextual teaching and learning. Preparing students for the new economy. Ohio:Bowling Green State University, 2001.

[7] Thomas, J.W., A review of research on project-based learning. Taken on September 16, 2008, from http://www. bie.org/research/stydy/ reviewofpro-jectbasedlearning 2000 .

[8] Lickona, Thomas, Educating for Character: How Our School Can Teach Respect and Responsibility. New York, Toronto, London, Sydney, Aucland: Bantam Books, 1991

[9] Kirschenbaum, H., Enhance Values And Morality In Schools And Youth. Boston: Allyn and Bacon, 1995.

[10] Zuchdi, Darmiyati, Grand Design Character Education And Values The Target. Yogyakarta: UNY Press, 2009.

[11] Borg, W.R., \& Gall, M. D., Educational Research, an introduction. New York: Longman, 1998.

[12] Zins, Joseph E., et.al., Building Academic Success on Social and Emotional Learning: What Does the Research Say? New York: Teachers College Press, 2001. 